\title{
SOME UNUSUAL FINDINGS IN A FAMILY WITH FRIEDREICH'S ATAXIA
}

\author{
BY \\ PETER E. SYLVESTER \\ From the Royal Liverpool Children's Hospital and The Fountain Hospital, London
}

(RECEIVED FOR PUbliCATION NOVEMber 11, 1957)

\section{Introduction}

Friedreich's ataxia, a hereditary disorder of the nervous system, is characterized by the onset of ataxia of gait, weakness and clumsiness of the limbs, and dysarthria of speech in young patients of either sex. Loss of tendon reflexes, usually combined with extensor plantar responses and impairment of vibration and joint sense, is often found. Nystagmus is common. Complications include mental symptoms, kyphoscoliosis, pes cavus and claw hand. Cardiac complications often terminate the disease. These findings are associated with progressive degeneration of the spinocerebellar and corticospinal tracts, the posterior column and Clarke's column.

A family, in which a father and six of his children are believed to suffer from Friedreich's ataxia, is reported because of several unusual features. Notably, optic atrophy and nerve deafness are the most consistent findings, and upper and lower motor neurone disturbances appear more conspicuous than those of the spino-cerebellar system. The rate of progress of the disease varied considerably : one child died within two and a half months of the onset of symptoms, whilst others with muscle wasting appeared to remit during the period of observation.

Before the diagnosis was finally established in the members of this family many conditions were considered. These included tuberculous meningitis, Arnold-Chiari malformation, posterior fossa lesion, spinal tumour, progressive muscular atrophy, peripheral neuritis due to avitaminosis, diphtheria, lead poisoning, toxic myelitis, and syphilis of the nervous system and meninges.

\section{Family History}

The medical history of the family preceded the period of observation, 1955-1956, by at least 16 years. The family consisted of the parents and nine children, four of whom died, three of these had nervous symptoms and signs. Both parents were Gentiles and were unrelated. The mother, 45 years, was quite well with no muscular weakness or ataxia. She had a long standing internal strabismus of the left eye but there was neither optic atrophy nor nystagmus. She was not deaf. The father, 44 years, suffered from childhood poliomyelitis which resulted in shortening of one leg. He had severe impairment of hearing, poor vision, bilateral optic atrophy and normal hands. His gait though cumbersome, due to his shortened leg, did not appear ataxic and he walked well unaided. His visual and auditory symptoms were slowly progressive for a number of years. Enquiry into the family tree revealed no history of disease of the nervous system in other members (Fig. 1).

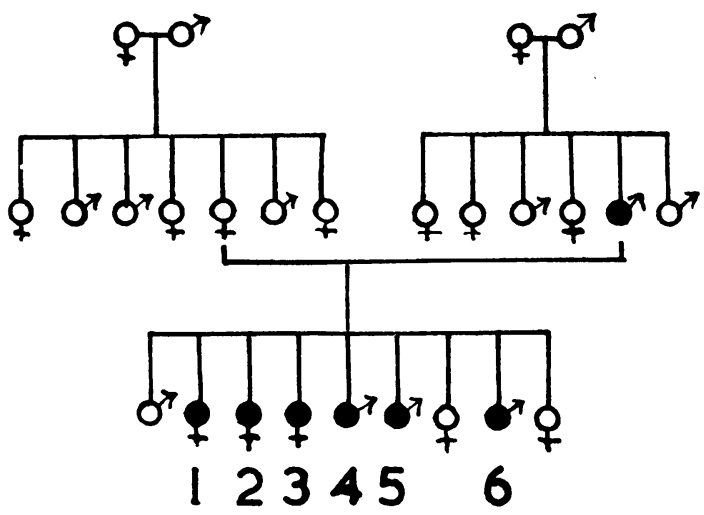

FIG. 1.-The family tree, with case numbers. - $=$ affected person.

The first child, a boy, not affected with nervous symptoms, was born in 1935 with bilateral talipes. He died of pneumonia at $3 \frac{1}{2}$ years. Necropsy revealed a well-nourished child with a large thyroid. Examination of the nervous system was not done.

Three girls and two boys who developed symptoms and signs of nervous disease were born in 1937 (Case 1), 1939 (Case 2), 1942 (Case 3), 1944 (Case 4) and 1946 
(Case 5). A daughter, born in 1948, was alive and well, but a son born in 1949 (Case 6) had nervous symptoms and signs. The youngest child, a daughter born in 1951, was unaffected and well.

Three children died (Cases 1, 2 and 5) and necropsies were done on two patients but, unfortunately, war damage destroyed reports and specimens. However, some specimens of Case 1 were obtained from the Pathology Department of Liverpool University and these are available for study. They include cross sections of the mid-brain, pons, medulla, cervical, thoracic and lumbo-sacral cord, and the optic nerve, which have been stained with haematoxylin and eosin, Loyez's and Marchi's methods.

Special investigations were carried out on some of the five patients. The results were as follows: (1) The Wassermann reaction was negative (Cases 2, 3, 4, 5, 6) and in both parents. (2) Toxoplasmosis dye and complement fixation tests (Cases 3, 4, 6) and in the mother were negative. (3) Radiographs of skull and spine (Cases 1, 2, 3, 4, 5) were normal with the exception of Case 3 which showed a slight degree of platybasia. (4) Electrocardiography, normal results (Cases 3, 4, 6). (5) Urinary lead, copper, amino acids and phenylpyruvic acid estimations were within normal limits (Cases 3, 4, 6). (6) Vitamin A absorption was within normal limits (Cases 3, 4, 6). (7) Plasma electrophoresis was normal (Cases 3, 4, 6). (8) Electromyography was normal (Case 6). (9) Muscle biopsy (Case 4) revealed normal muscle. (10) Cerebrospinal fluid appeared normal (Cases 1, 2, 3, 4, 6). If any comment could be made, it was that the sugar content showed a constant tendency towards the low side of normal (between 50 and $60 \mathrm{mg}$. $/ 100 \mathrm{ml}$.). (11) The fasting blood pyruvic acid was determined in Cases 3, 4 and 6 after the method of Friedemann and Haugen (1943). The value was within normal limits $(0.5$ to $1.1 \mathrm{mg} . / 100 \mathrm{ml}$.) in Cases 3 and 4 but raised $(1.7 \mathrm{mg} . / 100 \mathrm{ml}$.) in Case 6 . An hour after a loading dose of glucose the levels remained within normal limits ( 1.7 to $2.3 \mathrm{mg} . / 100 \mathrm{ml}$.) in Cases 3 and 4 , but in Case 6 a raised value persisted $(3.1 \mathrm{mg} . / 100 \mathrm{ml}$.). The reason for this was not clear.

All the affected children were born normally and were healthy infants. Milestones (holding up the head, sitting, standing and walking) were passed normally. Up to the onset of symptoms all had been healthy with the exception of Case 2, who had a sacrococcygeal pelvic tumour removed surgically at 9 months, and Case 6 , who had a congenital strabismus at 3 years which had been satisfactorily corrected by the time symptoms developed. Cases 3, 4 and 6 suffered minor head injuries but these were not severe enough to cause concussion.

Impairment of vision and hearing were the most constant symptoms in children and father; slow to start, they were gradually progressive. There was no history of middle-ear disease. A similar picture was seen in the optic fundi of the father and Cases 2, 3, 4, 5, and 6 . The discs, uniformly pale, stood out distinctly from an apparently normal retina. In Case 2 the left disc was involved but in the others both discs were affected. In Case 1 the fundi were thought to be healthy during life but after death demyelination of the optic nerve was found. Fields of vision (Cases 3,4) showed peripheral constriction with no central scotoma. Light reflexes, where noted, were present (Cases 2, 4, 5, 6). Tests for the auditory nerve (Rinne and Weber) revealed impairment of bone and air conduction. The tympanic membranes appeared healthy. On this evidence it was assumed that deafness was nervous in origin. The degree of deafness varied; it was slight in Cases 1, 2, and 6, moderate in Case 4 and severe in Cases 3 and 5, causing Case 3 to attend a school for the deaf, where her poor visual acuity restricted her ability to learn lip reading. All the patients learnt to speak, if somewhat monotonously and monosyllabically, and were not considered to be grossly dysarthric.

Four children had nystagmus (Cases 1, 2, 4, 5). In Case 1 it occurred in all directions, it was horizontal in Cases 2 and 4, and rotatory in Case 5. The facies were expressionless and on smiling the lips were transverse. Other cranial nerves appeared intact, with no other signs of bulbar involvement.

None of the patients had convulsions or tremors. Mentally, they were dull and were either irritable (Cases 1, 5) or apathetic (Cases 2, 6). Acute fright and attacks of clinging to the mother overcame Case 5 periodically.

To add to the misery of this family, the parents often quarrelled about their responsibility for the children's plight. In particular, the father blamed the mother, because of the 'turn in her eye', which he considered to be the cause of the children's eye trouble, and as a result he often sought the companionship of other women thereby creating a further difficulty.

Other physical findings are listed in Table 1.

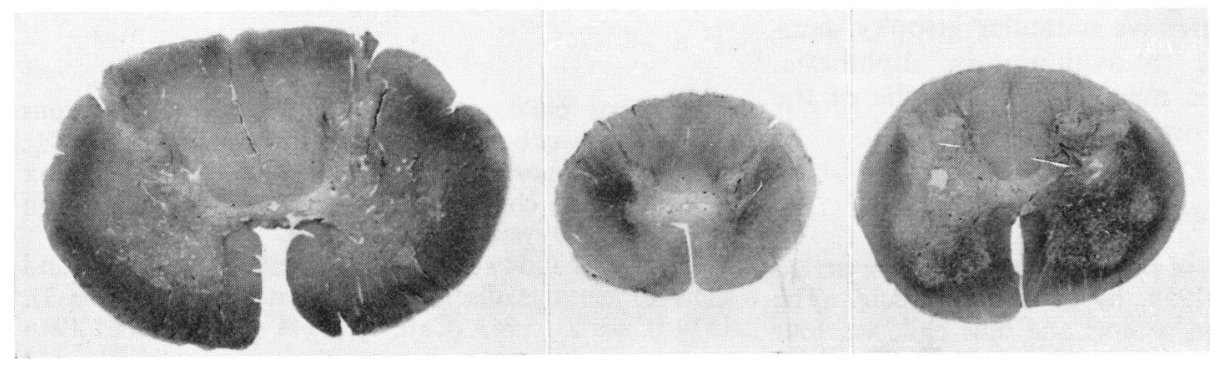

Fig 2.-Demyelina-
tion of posterior
columns, dorsal and
ventral spino-cerebel-
lar tracts in sections of
cord at cervical,
thoracic, and sacral
levels. Loyez $\times 5$. 
TABLE 1

PHYSICAL FINDINGS IN FAMILY WITH FRIEDREICH'S ATAXIA

\begin{tabular}{|c|c|c|c|c|c|c|c|c|}
\hline \multirow{2}{*}{\multicolumn{3}{|c|}{ Case No. }} & 1 & 2 & 3 & 4 & 5 & 6 \\
\hline & & & Female & Female & Female & Male & Male & Male \\
\hline \multicolumn{3}{|c|}{ Age of onset (in years) } & $2 ! 2$ & $7 \frac{3}{4}$ & 9 & 9 & $51 / 6$ & $51 / 6$ \\
\hline \multicolumn{3}{|l|}{$\begin{array}{l}\text { Symptoms: } \\
\text { presenting }\end{array}$} & Fatigue & $\begin{array}{l}\text { Impaired } \\
\text { hearing }\end{array}$ & $\begin{array}{l}\text { Impaired } \\
\text { hearing }\end{array}$ & Failing vision & $\begin{array}{l}\text { Difficulty in } \\
\text { fastening } \\
\text { buttons, turning } \\
\text { doorknobs }\end{array}$ & $\begin{array}{l}\text { Leaning on } \\
\text { things for } \\
\text { support }\end{array}$ \\
\hline subsidiary & $\cdots$ & $\cdots$ & $\begin{array}{l}\text { Weakness and } \\
\text { leaning on } \\
\text { things for } \\
\text { support. Rolling } \\
\text { of eyes. Un- } \\
\text { steadiness of } \\
\text { hands when } \\
\text { holding objects }\end{array}$ & $\begin{array}{l}\text { Weakness of } \\
\text { hands. 'Pins } \\
\text { and needles' in } \\
\text { hands, feet. } \\
\text { Unsteadiness in } \\
\text { walking, with } \\
\text { stiff legs, high } \\
\text { steppage }\end{array}$ & $\begin{array}{l}\text { Unsteady gait. } \\
\text { Poor vision. } \\
\text { Headaches }\end{array}$ & $\begin{array}{l}\text { Deterioration in } \\
\text { hearing }\end{array}$ & $\begin{array}{l}\text { Deafness. } \\
\text { Irritability. } \\
\text { Muscle weak- } \\
\text { ness. Difficulty } \\
\text { in walking: often } \\
\text { toppled for- } \\
\text { ward. Failing } \\
\text { vision }\end{array}$ & $\begin{array}{l}\text { Difficulty in } \\
\text { fastening belt } \\
\text { clasp }\end{array}$ \\
\hline duration & $\cdots$ & $\cdots$ & $\begin{array}{l}\text { Died within } 2 ! \\
\text { mth. from } \\
\text { 'demyelinating } \\
\text { myelitis' }\end{array}$ & $\begin{array}{l}\text { Died } 19 \text { mth. } \\
\text { later from 'toxic } \\
\text { polyneuritis' }\end{array}$ & $4 \mathrm{yr}$. & $1 \mathrm{yr}$. & $\begin{array}{l}\text { Died } 3 \frac{1}{2} \text { yr. } \\
\text { later from } \\
\text { pneumonia }\end{array}$ & $8 \mathrm{mth}$ \\
\hline Past history .. & . & $\cdots$ & Healthy & $\begin{array}{l}\text { Sacrococcygeal } \\
\text { tumour removed } \\
\text { at } 9 \mathrm{mth} \text {. }\end{array}$ & $\begin{array}{l}\text { Minor head } \\
\text { injury }\end{array}$ & $\begin{array}{l}\text { Minor head } \\
\text { injury }\end{array}$ & Healthy & $\begin{array}{l}\text { Minor head } \\
\text { injury. } \\
\text { Congenital } \\
\text { strabismus at } \\
3 \text { yr. }\end{array}$ \\
\hline \multicolumn{2}{|l|}{$\begin{array}{c}\text { Motor Function: } \\
\text { Posture . . }\end{array}$} & $\cdots$ & Dorsal kyphosis & Normal & Lordosis & $\begin{array}{l}\text { Scoliosis. } \\
\text { Pes cavus }\end{array}$ & Claw hand & $\begin{array}{l}\text { Slumped forward } \\
\text { in sitting } \\
\text { position }\end{array}$ \\
\hline Tone $\quad \ldots$ & $\cdots$ & $\cdots$ & Poor in arms & Increased in legs & Normal & Normal & Increased in legs & Poor all limbs \\
\hline Power . . & $\cdots$ & $\cdots$ & $\begin{array}{l}\text { Weakness both } \\
\text { arms }\end{array}$ & $\begin{array}{l}\text { Weakness of } \\
\text { grip }\end{array}$ & Good & Good & $\begin{array}{l}\text { Weakness arms } \\
\text { and legs }\end{array}$ & $\begin{array}{l}\text { General weak- } \\
\text { ness }\end{array}$ \\
\hline Wasting .. & $\cdots$ & $\cdots$ & None & $\begin{array}{l}\text { Marked in small } \\
\text { muscles, hands, } \\
\text { deltoids }\end{array}$ & None & $\begin{array}{l}\text { Deltoids and } \\
\text { spinati, hands }\end{array}$ & $\begin{array}{l}\text { Deltoids with } \\
\text { scapular and } \\
\text { thenar muscles }\end{array}$ & $\begin{array}{l}\text { Supra and infra- } \\
\text { spinati }\end{array}$ \\
\hline Fibrillation & $\cdots$ & $\cdots$ & Not noted & None & Deltoids & Quadriceps & None & Spinati \\
\hline \multicolumn{2}{|l|}{$\begin{array}{l}\text { Sensory Function: } \\
\text { Tactile sensitivity }\end{array}$} & $\cdots$ & Not tested & Normal & Normal & Normal & Not tested & Not tested \\
\hline \multicolumn{2}{|c|}{ Pain sensitivity .. } & $\ldots$ & , & , & , & , & , & Normal \\
\hline \multirow{2}{*}{\multicolumn{2}{|c|}{$\begin{array}{l}\text { Joint position } \\
\text { Vibration sense }\end{array}$}} & $\cdots$ & , & Not tested & , & , & , & , \\
\hline & & $\cdots$ & , & Normal & Absent in ankles & Absent in ankles & , & , \\
\hline $\begin{array}{l}\text { Reflexes: } \\
\text { Plantar }\end{array}$ & . & . & Extensor & $\begin{array}{l}\text { Bilateral } \\
\text { extensor }\end{array}$ & Normal & Normal & Left extensor & Normal \\
\hline Abdominal & . & $\cdots$ & Absent & Present & Present & Present & Present & Present \\
\hline Deep $\quad \ldots$ & . & $\cdots$ & Not tested & $\begin{array}{l}\text { Increased } \\
\text { especially in } \\
\text { legs with knee } \\
\text { clonus }\end{array}$ & $\begin{array}{l}\text { Absent ankle } \\
\text { jerks }\end{array}$ & Diminished & $\begin{array}{l}\text { Diminished but } \\
\text { increased left } \\
\text { leg }\end{array}$ & Normal \\
\hline $\begin{array}{l}\text { Coordination: } \\
\text { Finger to nose }\end{array}$ & test & . & Not tested & Normal & Normal & $\begin{array}{l}\text { Intention } \\
\text { tremor right } \\
\text { hand }\end{array}$ & Not tested & Normal \\
\hline Heel to knee. & . & $\cdots$ & ", & Not tested & , & Normal & ," & , \\
\hline Rombergism & . & $\cdots$ & , & Positive & Positive & Positive & , & Negative \\
\hline
\end{tabular}

Histology

Examination of the sections from Case 1 showed that degenerative changes were most marked in the cord (Fig. 2) where symmetrical demyelination involved the tracts of Goll and Burdach, the anterior and posterior spino-cerebellar tracts and the cortico-spinal tracts. Demyelination could be discerned in the area of Monakow and lateral aspect of the restiform body in the medulla, but the pyramids and the medial lemnisci appeared intact. The normal orderly arrangement of 
the axons was replaced by many irregular distended spaces. Towards the periphery of the involved tracts the contents of many of these spaces stained with osmic acid. Axis cylinders were difficult to define and it was not possible to say whether they were reduced in number. The anterior and posterior nerve roots stained with osmic acid.

The entire grey matter of the cord was congested, there was no oedema or perivascular cuffing. Two haemorrhagic cystic spaces had formed in the postero-lateral regions of the grey matter in the sacral cord. The walls of the vessels in the cord and meninges appeared normal and so did the meninges.

There was widespread damage of nerve cells. Some stained densely, the nucleus being eccentric and the chromatin network lost. Others appeared swollen and contained a feebly stained and eccentric nucleus, the chromatin being either arranged around the periphery of the cell or completely absent. Satellitosis was observed around some of the swollen cells.

Areas showing nerve cell damage included the grey matter of the cord (in one thoracic section they were completely absent), the cuneate nucleus, the Vth nerve nucleus, and the substantia nigra. Both anterior and posterior horns of the cord were affected as well as Clarke's column. Glial cells appeared increased in both grey and white matter.

Concentric demyelination was seen in the optic nerve.

Two sections of the cord and one of the optic nerve were stained by Holzer's method. By this means an increase of glial tissue was demonstrated in the posterior columns, the posterior spino-cerebellar tracts, the anterior horns, Clarke's column and in the optic nerve.

No abnormality could be detected in the vestibular nuclei and the trapezoid bodies. The auditory pathway could not be studied in the limited number of sections available. The superior and medial accessory olivery nuclei, the pontine nuclei, the $\mathrm{Xth}$ and XIIth nerve nuclei appeared normal.

\section{Discussion}

Diagnosis. Even when it became clear that the disorder was heredo-familial, its nature remained uncertain because the clinical picture varied so much. Bogaert (1948) observes that the more complex a heredo-degenerative disease seems anatomically, the more it appears to merge with other groups. For this reason familial amyotrophic lateral sclerosis was diagnosed in Cases 3, 4, 5 and 6 because signs of upper and lower motor neurone disease were prominent. However, posterior column loss (Cases 3, 4), nystagmus (Cases 4,5 ) and intention tremor (Case 5) cast doubt upon this diagnosis.

Greenfield (1954) discusses the association of Charcot-Marie-Tooth and Roussy-Levy syndromes with Friedreich's ataxia because their pathological features are similar in some respects. The points of clinical similarity with these syndromes in the present family are 'main-en-griffe' (Case 5), reduction of the deep reflexes (Cases 3, 4, 5), spinal deformities
(Cases 1, 3, 4), remissions (Case 6) and degeneration in dorsal columns, pyramidal and spino-cerebellar tracts and loss of cells in Clarke's column. Points of difference are the presence of nystagmus, intention tremor and absence of characteristic wasting of the peroneal and anterior tibial muscles.

Friedreich's ataxia was considered the most likely diagnosis in the light of all the symptoms and signs of the patients and the histopathology of Case 1.

Optic Atrophy and Nerve Deafness. Optic atrophy is not uncommon in Friedreich's ataxia; Sjögren (1943) found an incidence of $12 \%$. The form varies, as in other hereditary ataxias. A retinal type, in which there is degeneration of the retina and choroid with an increase in pigmentation was described by Franceschetti and Klein (1948), and designated 'tapeto-retinal degeneration'. Neuritis of the optic nerve head and retrobulbar neuritis may also be seen. André-van-Leeuwen (1948) suggested three varieties of this form.

The first shows typical retrobulbar neuritis in which vision is rapidly diminished, sometimes considerably, there is a central scotoma and temporal pallor of the disc. Peripheral fields are usually little affected. Sometimes lesions extend beyond the papillo-macular bundle when there is deficiency in the peripheral fields of vision. The age of onset is 30 to 40 years.

The second shows rapid onset of optic nerve degeneration with considerable loss of vision almost to the point of complete blindness. The disc is pale and there is considerable shrinkage of the visual fields. In less advanced cases central as well as peripheral vision may be lost. This type usually comes on about puberty although it may appear congenitally or in early infancy.

The third shows loss of vision of less sudden onset with peripheral constriction of the visual fields which is seen more typically in the spino-pontocerebellar degenerations. Pallor of the discs may be complete or confined to the temporal halves. Sometimes, a discordance between loss of central and peripheral vision may be noticed. Even when a central scotoma is present it may be uncertain whether it is due to retrobulbar neuritis. At other times the picture is that of a slowly progressing optic atrophy. The age of onset is variable and the course slow. The findings in the present family resembled this third type.

Atrophic changes in the papillo-macular bundle of the optic nerve, chiasma and tracts was described by Bogaert in an 11-year-old child with Leber's disease, who died of cerebral haemorrhage and whose cord showed lesions of similar type to those found in Friedreich's ataxia. 
André-van-Leeuwen comments that, exceptionally, optic atrophy may precede other nervous symptoms. Sometimes it appears simultaneously, but mostly it follows other symptoms, often by a number of years.

Nerve deafness is much rarer than optic atrophy and their combination is unusual. Bogaert (1948) describes three brothers who suffered from Friedreich's ataxia, two of whom had central deafness and optic atrophy, in whom he regards inheritance as recessive. Unfortunately, necropsies were not carried out, but, in another type of hereditary ataxia, Nyssen and Bogaert (1934) described lesions in a brother and sister in whom there was demyelination of the optic chiasma and degeneration of the primary and secondary pathways of the cochlear system. Degenerated fibres were traced through the restiform body, cochlear nucleus, superior olivery nucleus, trapezoid body, Monakow's bundle and the medial lemniscus to the corpora quadrigemina and internal geniculate body. The cord was not examined. The limited number of sections in the present family made it impossible to compare accurately the histological findings; there was no degeneration of the trapezoid bodies, the medial lemnisci or superior olivery nuclei, but demyelination was present in Monakow's area and the restiform body. Urich, Norman and Lloyd (1957) in studying the auditory pathway of a $10 \frac{1}{2}$-year-old girl, who suffered from Friedreich's ataxia, found widespread loss of cells in the central cochlear nucleus. Deafness was not detected clinically but audiometric studies were not done.

Matthews (1950) reported deaf-mutism in three siblings with symptoms and signs of Friedreich's ataxia. A fourth sibling with similar peripheral signs was not a deaf mute.

Clinical evidence of involvement of the vestibular branch of the VIIIth nerve (loss of caloric reaction) was found by Guillain, Mollaret and Aubrey (1935) in 18 cases of Friedreich's ataxia. They found nerve deafness to be rare. They claim that vestibular investigation in Friedreich's ataxia may have some diagnostic value.

Montandon (1948) discusses the auditory, anatomical and pathological implications in hereditary ataxias, and concludes that most lesions causing deafness commence in the labyrinth and may be so slight as to escape detection unless sought carefully by audiometry. The degenerative process tends to spread centrally and when this occurs central deafness masks labyrinthine deafness.

General Comments. Pathogenesis is discussed in most textbooks of neurology and by Greenfield (1954) and will not be repeated here.

The genetic basis of Friedreich's ataxia is beyond doubt. It may be transmitted by dominant or recessive genes. In the present family it is dominant. Some idea of the frequency with which each type occurs is given by Bell (1948) who analysed the findings in 500 pairs of siblings thought to be recessive in origin and 144 pairs thought to be dominant. From the analysis it was found that the age of onset in both groups was similar and that there was a marked tendency for siblings of one family to present symptoms at the same period of life. This last fact may have practical prognostic implications for unaffected and much older siblings, but in the present family in which there are two young unaffected siblings, conclusions on this point cannot yet be drawn.

Matthews suggested that when deaf mutism occurs it may be due to the chance association of two genes. It seems more likely that all the clinical and pathological findings are due to the same process and are attributable to the same causal factor. Diverse anatomical changes in the nervous system, similar to those found in Friedreich's ataxia, have been caused in animals by vitamin A deficiency (Mellanby, 1934) and it seems reasonable to deduce that one gene acting in some similar manner might be responsible for all findings.

\section{Summary}

The clinical findings in a family, consisting of a father and six of his children believed to suffer from Friedreich's ataxia, are presented. An unusual feature is the presence of optic atrophy and nerve deafness.

Histological findings in the cord, medulla and midbrain are described.

My thanks are due to Professor N. B. Capon and Dr. R. W. Brookfield for access to their case records at the Royal Liverpool Children's Hospital, and to Dr. J. S. Elwood who helped me with the histology. My colleagues at the Fountain Hospital were kind enough to offer helpful criticism.

\section{REFERENCES}

André-van-Leeuwan, M. (1948)，Rev, oto-neuro-ophtal,, 20, 43.

Bell, J. (1943). Treasury of Human Inheritance. Vol. 4. London. Bogaert, L. van (1948). Modern Trends in Ophthalmology, Vol. II, edited by Arnold Sorsby, London.

Franceschetti, A. and Klein, D. (1948). Rev. oto-neuro-ophtal., 20, 109.

Friedemann, T. E. and Haugen, G. E. (1943). J. biol. Chem., 147, 415.

Greenfield, J. G. (1954). The Spino-Cerebellar Degenerations. Amer. Lect. Ser. No. 244 . Oxford.

Guillain, G., Mollaret, P. and Aubrey, M. (1935). Rev. neurol. (Paris), 63, 36.

Matthews, W. B. (1950). J. Neurol. Neurosurg. Psychiat., 13, 307.

Mellanby, E. (1934). Nutrition and Disease. Edinburgh and London.

Montandon, A. (1948). Rev. oto-neuro-ophtal., 20, 181.

Nyssen, R. and Bogaert, L. van (1934). Rev. neurol.'(Paris), (II), 321. Sjögren, T. (1943). Klinische und erbbiologische Untersuchungen über die Heredoataxien. Copenhagen. Also in Acta Psychiat. Neurol. (Kbh.), Suppl. 27.

Urich, H., Norman, R. M. and Lloyd, O. C. (1957). Confin. Neurol. (Basel), 17, 360. 